\title{
THE
}

\section{Green-Water Rearing and Delayed Weaning Improve Growth and Survival of Summer Flounder}

\author{
David A. Bengtson \\ University of Rhode Island, bengtson@uri.edu \\ Lindsay Lydon \\ University of Rhode Island \\ Jeffrey D. Ainley \\ University of Rhode Island
}

Follow this and additional works at: https://digitalcommons.uri.edu/favs_facpubs

Terms of Use

All rights reserved under copyright.

\section{Citation/Publisher Attribution}

Bengtson, D. A., Lydon, L. and Ainley, J. D. (1999), Green-Water Rearing and Delayed Weaning Improve Growth and Survival of Summer Flounder. North American Journal of Aquaculture, 61: 239-242. doi:10.1577/1548-8454(1999)061<0239:GWRADW>2.0.C0;2

Available at: http://dx.doi.org/10.1577/1548-8454(1999)061<0239:GWRADW>2.0.C0;2

This Article is brought to you for free and open access by the Fisheries, Animal and Veterinary Sciences at DigitalCommons@URI. It has been accepted for inclusion in Fisheries, Animal and Veterinary Sciences Faculty Publications by an authorized administrator of DigitalCommons@URI. For more information, please contact digitalcommons-group@uri.edu. 
This article was downloaded by: [University Of Rhode Island]

On: 14 February 2013, At: 09: 14

Publisher: Taylor \& Francis

Informa Ltd Registered in England and Wales Registered Number: 1072954 Registered office: Mortimer House, 37-41 Mortimer Street, London W1T 3J H, UK

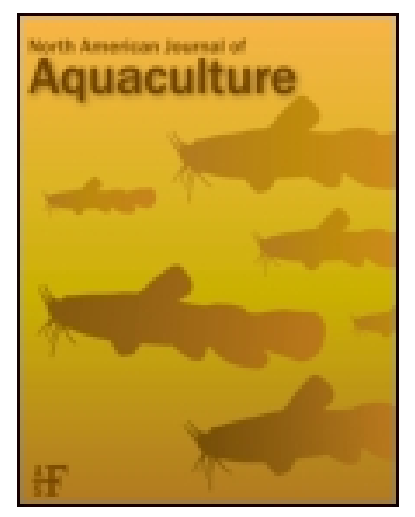

\title{
North American J ournal of Aquaculture
}

Publication details, including instructions for authors and subscription information:

http:// www. tandfonline.com/loi/ unaj 20

\section{Green-Water Rearing and Delayed Weaning Improve Growth and Survival of Summer Flounder}

\author{
David A. Bengtson ${ }^{a}$, Lindsay Lydon ${ }^{a} \&$ J effrey D. Ainley ${ }^{a}$ \\ ${ }^{a}$ Department of Fisheries, Animal and Veterinary Science, University of Rhode Island, \\ Kingston, Rhode Island, 02881, USA \\ Version of record first published: $09 \mathrm{~J}$ an 2011.
}

To cite this article: David A. Bengtson, Lindsay Lydon \& J effrey D. Ainley (1999): Green-Water Rearing and Delayed Weaning Improve Growth and Survival of Summer Flounder, North American J ournal of Aquaculture, 61:3, 239-242

To link to this article: http:// dx. doi.org/ 10.1577/ 1548-8454(1999)061<0239: GWRADW>2. 0. C0;2

\section{PLEASE SCROLL DOWN FOR ARTICLE}

Full terms and conditions of use: http://www.tandfonline.com/page/terms-and-conditions

This article may be used for research, teaching, and private study purposes. Any substantial or systematic reproduction, redistribution, reselling, loan, sub-licensing, systematic supply, or distribution in any form to anyone is expressly forbidden.

The publisher does not give any warranty express or implied or make any representation that the contents will be complete or accurate or up to date. The accuracy of any instructions, formulae, and drug doses should be independently verified with primary sources. The publisher shall not be liable for any loss, actions, claims, proceedings, demand, or costs or damages whatsoever or howsoever caused arising directly or indirectly in connection with or arising out of the use of this material. 
North American Journal of Aquaculture 61:239-242, 1999

(C) Copyright by the American Fisheries Society 1999

\title{
Green-Water Rearing and Delayed Weaning Improve Growth and Survival of Summer Flounder
}

\author{
David A. Bengtson,* Lindsay Lydon, and Jeffrey D. Ainley ${ }^{1}$ \\ Department of Fisheries, Animal and Veterinary Science, University of Rhode Island, \\ Kingston, Rhode Island 02881, USA
}

\begin{abstract}
The advent of an aquaculture industry for summer flounder Paralichthys dentatus requires that optimal methods be identified for hatchery production. Two experiments were conducted to test strategies for larval rearing and for weaning newly metamorphosed juveniles from live to artificial diets. Rearing of larvae in "green water" (with algae added) resulted in better survival $(76.1 \pm 6.5 \%)$ from days $5-42$ after hatching than did rearing in "clear water" (no algae added; $27.8 \pm$ $13.6 \%$ ), although no differences in growth were apparent. When fish were weaned from live feed beginning at day 45 versus day 57 by either a "gradual" method (7-d weaning period) or an "immediate" method (no weaning period), better survival and growth were obtained with fish weaned at the later age. For both agegroups, fish weaned by the gradual method exhibited better growth, but not better survival, than those weaned by the immediate method. With these data as examples, commercial hatcheries can conduct cost : benefit analyses of the different rearing methods.
\end{abstract}

Natural stocks of summer flounder Paralichthys dentatus, a commercially important species, are in decline (NMFS 1996). Commercial aquaculture of this species began in 1996, but strategies for optimal production still need to be established (Bengtson and Nardi, in press). Substantial mortality occurs during early larval stages and at the time of metamorphosis and weaning to formulated diets (Bengtson 1999). Hatchery production of summer flounder is modeled after that of the successful culture of turbot Scophthalmus maximus in Europe.

In the early $1990 \mathrm{~s}$, major turbot hatcheries in Europe had differing views on the optimal strategy for larval rearing. One group claimed that use of "green water" (i.e., with microalgae added to the rearing tanks) was most efficacious, whereas another group claimed that use of "clear water" (no microalgae added) allowed better control of the rearing system because fewer species were involved (G. Nardi, GreatBay Aquafarms, personal

\footnotetext{
* Corresponding author: bengtson@uriacc.uri.edu

${ }^{1}$ Present address: New England College of Optometry, 424 Beacon Street, Boston, Massachusetts 02115, USA.

Received May 11, 1998; accepted February 12, 1999
}

communication). Recent studies have determined that survival and growth of turbot larvae are greater in green water than in clear water (summarized by Reitan et al. 1997). Støttrup et al. (1995) proposed that the beneficial effect of the microalgae is a result of its control of bacteria rather than its nutritional effect.

Preliminary studies in our laboratory indicated no significant difference in survival of summer flounder larvae reared in green water versus clear water but significantly greater growth in green water; however, the results were influenced by large variance in survival among replicates, including very poor survival in one replicate of the greenwater treatment. The question arose whether green-water rearing might be generally better but carries the risk of occasional catastrophic loss of larvae. We therefore decided to conduct a more thorough experiment to assess the benefits and risks of rearing summer flounder larvae in clear versus green water.

Summer flounder spend about 35-65 d as swimming, bilaterally symmetrical larvae in small experimental tanks at $20^{\circ} \mathrm{C}$ before they metamorphose and settle to the bottom. Faster growing larvae settle at an earlier age than slower growing larvae. The digestive tract is complete (including a stomach) and functional at about the time of metamorphosis (Bisbal and Bengtson 1995; Huang et al. 1998). A significant problem in the hatchery rearing of marine fish is the transition from a diet of live prey organisms, usually nauplii of brine shrimp Artemia sp., to a formulated dry diet. The time after hatch at which this transition (often referred to as weaning) can be made varies from species to species, but it generally occurs after the stomach has developed. For many species, especially flatfish, the stomach is complete only after metamorphosis and settlement from the water column to the bottom. Nevertheless, this period of transition from live to formulated diet can be a period of high mortality, as some fish apparently never eat the formulated diet and eventually starve. Recent reviews of formulated diets for young fish (Person-Le Ruyet et al. 1993; Rosenlund et al. 
1997) have concentrated on attempts to feed them to larvae before metamorphosis, but optimal strategies for weaning from live to formulated diets even after metamorphosis have been established for very few species. The strategy used in most hatcheries is to gradually diminish the amount of live food provided and gradually increase the amount of formulated diet. Several aspects of weaning have been investigated in turbot (Bromley and Howell 1983; Bromley and Sykes 1985; Segner and Witt 1990). It appears from those studies that older turbot are easier to wean than younger and that duration of time to establish weaning is variable. More recently, Lee and Litvak (1996) found that wild-caught winter flounder Pleuronectes americanus could be weaned to a dry diet in 1 week, but Daniels and Hodson (1999) found that 12-20 d of weaning were required for southern flounder Paralichthys lethostigma.

We conducted preliminary experiments on newly metamorphosed summer flounder in small bowls and found that, in some cases, a gradual change from live to formulated diets worked well. In other cases, fish would not ingest the formulated diet at all if any live food was provided at any time during the day, but immediately ingested the formulated diet if no live food was provided. We therefore decided to conduct an experiment to simultaneously examine the success of weaning at two ages (begin weaning at $45 \mathrm{~d}$ after hatch (DAH) versus $57 \mathrm{DAH}$ ) and with two methods of weaning (gradual weaning over $7 \mathrm{~d}$ versus immediate weaning from pure live food one day to pure formulated diet the next).

\section{Methods}

Summer flounder were obtained from broodstock fish at the University of Rhode Island and reared according to methods described by Bisbal and Bengtson (1993). The green- water versus clear-water experiment was designed as a twotreatment experiment, with 10 replicates in each treatment. Each replicate chamber (a 75-L glass aquarium with blackened walls) contained $60 \mathrm{~L}$ of filtered seawater $\left(30 \pm 2 \%\right.$ salinity, $\left.20 \pm 2{ }^{\circ} \mathrm{C}\right)$ and 6005 -d-old larvae at the beginning of the experiment. The larvae were randomly distributed to the 20 aquaria in the experiment. The experiment continued until the fish were $42 \mathrm{~d}$ old. Larvae were given only rotifers Brachionus plicatilis until they were $17 \mathrm{~d}$ old, then given both rotifers and brine shrimp nauplii for 1 week, then given brine shrimp only until the end of the experiment. Food levels were monitored on each day of the experiment and maintained at approximately 5 rotifers $/ \mathrm{mL}$ and 1 brine shrimp nauplius/mL. Approximately $90 \%$ of the water in each aquarium was replaced during each twice-weekly water exchange in the semistatic system. Light was provided by a $15-\mathrm{W}$ fluorescent aquarium light over each aquarium. The green-water aquaria received the addition of approximately $600 \mathrm{~mL} / \mathrm{d}$ of the green alga Tetraselmis suecica (stock culture density approximately $1 \times 10^{6}$ cells $/ \mathrm{mL}$ ), and the water in the aquaria was visibly green throughout the experiment. At the end of the experiment, all the fish in each aquarium were counted and removed and random subsamples (every 15th fish from the green-water aquaria and every 6th fish from the clear-water aquaria) were collected for measurement of total length. Both survival and total length results were analyzed by $t$-tests with results considered significant at the $P<0.05$ level.

Larvae in the weaning experiment were fed rotifers and then brine shrimp nauplii before use in the experiment. Approximately 1 week after settlement began, settled fish were siphoned from the rearing aquaria and placed in a single 190-L aquarium, so that all the fish used in the experiment would initially be at the same developmental stage. The experiment was designed as a $2 \times 2$ factorial, with age and weaning method as the factors. The treatments were (1) fish weaned beginning at 45 DAH using the immediate method (45-I), (2) fish weaned beginning at $45 \mathrm{DAH}$ using the gradual method (45-G), (3) fish weaned beginning at 57 DAH using the immediate method (57-I), and (4) fish weaned beginning at $57 \mathrm{DAH}$ using the gradual method (57-G). Each treatment consisted of four replicates (75-L aquaria) containing 25 fish each. Two hundred fish were removed from the stock tank and randomly placed in the experimental aquaria at $45 \mathrm{DAH}$ (average initial wet weight, $26 \mathrm{mg}$ ). The remainder of the fish were left in the stock tank and fed brine shrimp nauplii. At 57 DAH, 200 more fish were removed from the stock tank and randomly distributed to the remaining experimental aquaria (average initial wet weight, $122 \mathrm{mg}$ ).

In the immediate treatments, no brine shrimp nauplii were supplied, and fish were given a commercially available weaning diet (Lansy, INVE Aquaculture). In the gradual treatments, over the course of a week, the fish were given one-seventh less brine shrimp each day than they received on the previous day and a concomitant increase each day of the Lansy diet to replace the reduction in brine shrimp. The aquaria were siphoned clean 
TABLE 1.-Survival and growth (mean \pm SD) of recently metamorphosed summer flounder weaned from live feed (brine shrimp nauplii) to a formulated diet (Lansy) at two ages ( $45 \mathrm{~d}$ after hatch [DAH] versus $57 \mathrm{DAH}$ ) by two methods (gradual versus immediate). Values within a column that are followed by the same letter are not statistically significantly different $(P>0.05)$.

\begin{tabular}{llc}
\hline \multicolumn{1}{c}{ Treatment } & $\begin{array}{c}\text { Survival } \\
(\%)\end{array}$ & $\begin{array}{c}\text { Final wet weight } \\
(\mathrm{mg})\end{array}$ \\
\hline 45 DAH, immediate & $55 \pm 24 \mathrm{y}$ & $63.4 \pm 20.2 \mathrm{w}$ \\
45 DAH, gradual & $69 \pm 14 \mathrm{y}$ & $92.6 \pm 8.5 \mathrm{x}$ \\
57 DAH, immediate & $78 \pm 11 \mathrm{z}$ & $141.7 \pm 22.4 \mathrm{y}$ \\
57 DAH, gradual & $85 \pm 4 \mathrm{z}$ & $176.8 \pm 46.4 \mathrm{z}$ \\
\hline
\end{tabular}

each day before feeding and any mortalities were counted and removed. At the end of the experiment at $89 \mathrm{DAH}$, all fish were removed from the aquaria, and wet weight of each fish was determined. Both survival and growth data were analyzed by twoway analysis of variance (ANOVA), and results were considered significant at the $P<0.05$ level.

\section{Results and Discussion}

Survival (mean $\pm \mathrm{SD}$ ) was significantly greater in the green-water aquaria $(76.1 \pm 6.5 \%)$ than in the clear-water aquaria $(27.8 \pm 13.6 \%)$. Total length (mean $\pm \mathrm{SD}$ ) was not significantly different between treatments $(9.8 \pm 0.7 \mathrm{~mm}$ in green water; $11.7 \pm 2.3 \mathrm{~mm}$ in clear water). The results indicate that green-water rearing was more effective than clear-water, both in the absolute magnitude of the survival percentage and the lower variability observed (coefficients of variation were $8.5 \%$ for green water; $48.9 \%$ for clear water). We conclude that survival is better and less variable in greenwater than in clear-water rearing of summer flounder larvae. Alves et al. (1999) also reported better and less variable survival in green water versus clear water for summer flounder larvae reared from $3 \mathrm{DAH}$ to $10 \mathrm{DAH}$ at high density in experimental 2-L bowls.

Fish weaned at 57 DAH survived and grew significantly more than those weaned at $45 \mathrm{DAH}$ and fish weaned by the gradual method grew significantly more than those weaned by the immediate method but did not survive significantly better ( $\mathrm{Ta}-$ ble 1). These results are in accord with the results of the other studies on flatfish weaning cited above. Given the results of Daniels and Hodson (1999), it may well be that higher survival rates could be obtained with summer flounder if a weaning period even longer than $7 \mathrm{~d}$ were used. The justification usually given for early weaning is that costs of rearing could be reduced if feeding on expensive brine shrimp nauplii could be minimized. Hatchery operators can use our data to estimate the costs and benefits of strategies of earlier versus later weaning, given known costs of brine shrimp and formulated diet and the calculated cost of fish mortalities at the weaning stage (i.e., how much they had invested in each fish that might die if weaned too early). Our anecdotal observations during and since this experiment suggest that more information is needed to identify optimum weaning factors for summer flounder (e.g., fish density, method and timing of food presentation, diet quality, and others). Mortality during weaning is still unacceptably high in this species and considerable research is still required to overcome that problem.

\section{Acknowledgments}

This research was supported by SaltonstallKennedy grant NA46FD0330. We thank the personnel of the Environmental Laboratory at Northeast Utilities' Millstone Division for providing broodstock fish, and we are grateful to Ed Baker for his expertise in spawning and raising the fish until they were used in the experiments.

\section{References}

Alves, D. A., J. L. Specker, and D. A. Bengtson. 1999. Investigations into the causes of early larval mortality in cultured summer flounder (Paralichthys dentatus L.). Aquaculture 176:155-172.

Bengtson, D. A. 1999. Aquaculture of summer flounder (Paralichthys dentatus): status of knowledge, current research, and future research priorities. Aquaculture 176:39-49.

Bengtson, D. A., and G. Nardi. In press. Summer flounder (Paralichthys dentatus). In R. R. Stickney, editor. Encyclopedia of aquaculture. Wiley, New York.

Bisbal, G. A., and D. A. Bengtson. 1993. Reversed asymmetry in laboratory-reared summer flounder, Paralichthys dentatus L. Progressive Fish-Culturist 55:106-108.

Bisbal, G. A., and D. A. Bengtson. 1995. Development of the digestive tract in larval summer flounder, Paralichthys dentatus. Journal of Fish Biology 47:277291.

Bromley, P. J., and B. R. Howell. 1983. Factors influencing the survival and growth of turbot larvae, Scophthalmus maximus L., during the change from live to compound feeds. Aquaculture 31:31-40.

Bromley, P. J., and P. A. Sykes. 1985. Weaning diets for turbot (Scophthalmus maximus L.), sole (Solea solea L.) and cod (Gadus morhua L.). Pages 191211 in C. B. Cowey, A. M. Mackie, and J. G. Bell, editors. Nutrition and feeding in fish. Academic Press, London.

Daniels, H. V., and R. G. Hodson. 1999. Weaning success of southern flounder juveniles: effect of changeover period, and diet type on growth, and 
survival. North American Journal of Aquaculture 61:47-50.

Huang, L., A. M. Schreiber, B. Soffientino, D. A. Bengtson, and J. L. Specker. 1998. Metamorphosis of summer flounder (Paralichthys dentatus): thyroid status and the timing of gastric gland formation. Journal of Experimental Zoology 280:413-420.

Lee, G. W. Y., and M. K. Litvak. 1996. Weaning of wild young-of-the-year winter flounder Pleuronectes americanus (Walbaum) on a dry diet: effects on growth, survival and feed efficiency ratios. Journal of the World Aquaculture Society 27:30-39.

NMFS (U.S. National Marine Fisheries Service). 1996. Fisheries of the U.S. current fishery statistics, no. 9500. NMFS, Silver Spring, Maryland.

Person-Le Ruyet, J., J. C. Alexandre, L. Thebaud, and C. Mugnier. 1993. Marine fish larvae feeding: for- mulated diets or live prey? Journal of the World Aquaculture Society 24:211-224.

Reitan, K. I., J. R. Rainuzzo, G. Oie, and Y. Olsen. 1997. A review of the nutritional effects of algae in marine fish larvae. Aquaculture 155:207-221.

Rosenlund, G., J. Stoss, and C. Talbot. 1997. Co-feeding marine fish larvae with inert and live diets. Aquaculture 155:183-191.

Segner, H., and U. Witt. 1990. Weaning experiments with turbot (Scophthalmus maximus): electron microscopic study of the liver. Marine Biology 105: 353-361.

Støttrup, J., K. Graveningen, and N. H. Norsker. 1995. The role of different algae in the growth and survival of turbot larvae (Scophthalmus maximus L.) in intensive rearing systems. ICES Marine Science Symposia 201:173-186. 